\title{
Contributions of Dent Corn Germplasm to Stalk and Root Quality in Sweet Corn
}

\author{
C.L. Treat and W.F. Tracy ${ }^{1}$ \\ Department of Agronomy, University of Wisconsin-Madison, Madison, WI 53706.
}

Additional index words. Zea mays, root pull, stalk crushing, lodging

\begin{abstract}
Root or stalk lodging can be a serious problem in sweet corn (Zea mays L.) production. Four dent corn inbreds, crossed to five sweet corn inbreds in a design II mating system, and a half diallel with five sweet corn inbreds were used to 1) determine the effect and potential contribution of dent corn germplasm on stalk and root quality traits in sweet corn, 2) examine the variation for stalk and root quality traits in some sweet corn germplasm, and 3) evaluate the utility of traits used in improving dent corn root and stalk quality in sweet corn improvement. The dent corn germplasm used in this study had a favorable affect on stalk and root quality in the dent $\times$ sweet hybrids. Compared to the sweet $\times$ sweet hybrids, the dent $\times$ sweet hybrids had significantly higher stalk crushing strength and stalk soluble carbohydrates, while having significantly less stalk lodging. The mean stalk lodging for the dent $\times$ sweet hybrids was $4.4 \%$, while the sweet $\times$ sweet hybrids averaged $18.7 \%$. Within the diallel, effects due to hybrids were highly significant for stalk section weight, rind thickness, and stalk diameter. Percent stalk lodging was negatively correlated with stalk section weight $[r=(-0.63), P \leq$ $0.05]$ and crushing strength $[r=(-0.64), P \leq 0.05]$. No traits were significantly correlated with root lodging within the sweet corn crosses. Dent corn has potential as a source of improved stalk and root quality in sweet corn.
\end{abstract}

Traits that affect eating quality and ear and kernel appearance (table quality), such as pericarp tenderness, kernel row count, husk extension, row configuration, kernel color, flavor, and texture, are of prime importance in sweet corn breeding programs. Other quality factors, yield, disease and pest resistance, and other agronomic traits vary in importance depending on the end use. Because of the importance of table quality traits, sweet corn breeders have exerted less selection pressure for certain agronomic traits, such as stalk and root quality, than have field corn breeders. Consequently, sweet corn varieties have relatively poor stalks and roots. The commercial sweet corn crop is harvested before seed maturity, and stalk lodging is not a major problem. It may be a problem, however, in seed production. Root lodging is a problem in commercial sweet corn production. Each year, processing companies abandon whole fields of hybrid sweet corn in the major processing region of the U.S. upper Midwest, because they are not harvestable due to root lodging. An understanding of the inheritance of these stalk quality traits and sources of variation would be useful in sweet corn improvement.

In contrast with sweet corn, the great importance of stalk and root quality as a breeding objective in dent corn has resulted in significant gains in stalk and root quality, while also improving yield (Russell, 1986). In a review of breeding methods, dent corn breeders ranked yield, stalk quality, and root quality as the most important characters (Bauman, 1981).

The preferred traits for evaluating stalk and root quality are actual stalk and root lodging, but environmental conditions do not always generate enough natural stalk and root lodging to allow differentiation. Traits that have been useful in evaluating stalk and root quality include stalk crushing strength, rind puncture resistance, rind thickness, weight of a stalk section, stalk breaking force, stalk sugar content, and vertical root pulling resistance (Chang and Loesch, 1972; Cloninger et al., 1970; Kevern and

Received for publication 28 Oct. 1992. Accepted for publication 30 Mar. 1993. Contribution from Wisconsin Agr. Expt. Sta. research supported by the College of Agr. and Life Sciences, Univ. of Wisconsin-Madison. This research was from a thesis by C.L.T. in partial fulfillment for the Ph.D. degree at the Univ. of WisconsinMadison. The cost of publishing this paper was defrayed in part by the payment of page charges. Under postal regulations, this paper therefore must be hereby marked advertisement solely to indicate this fact.

${ }^{1}$ To whom reprint requests should be addressed.
Hallauer, 1983; Mortimore and Ward, 1964; Twumasi-Afriyie and Hunter, 1982; Zuber and Loesch, 1962). These methods of measuring stalk and root quality are affected by environmental conditions and genotypes. Colbert and Zuber (1978) found that single crosses responded differently for rind puncture strength over sampling dates. In a study by Zuber and Loesch (1966), the environment had a greater effect on crushing strength and weight of a 51-mm stalk section than on rind thickness. However, they concluded that a single location in a single year was adequate to screen for stalk lodging resistance.

In the parental, $\mathrm{F}_{1}$, and backcross generations of stalk-lodgingresistant $\times$ susceptible crosses, the distributions of crushing strength and rind thickness were skewed toward the resistant parent (Loesch et al., 1963). There was a high correlation between the two traits, and specific combining ability (SCA) was greater than general combining ability (GCA) for both traits. In a diallel with $66 \mathrm{~F}_{1}$ s, where percentage stalk lodging, stalk diameter, stalk section weight, stalk density, crushing strength, and rind thickness were measured, GCA and SCA mean squares were almost always statistically significant, with GCA mean squares usually much larger than SCA mean squares (Loesch, 1972).

Some sweet corn breeders have used dent corn germplasm in breeding projects (Haber, 1945); however, dent corn germplasm is generally unacceptable for flavor, texture, and tenderness, and careful selection for these traits is necessary. Tracy (1990) showed that dent corn germplasm could contribute positively to sweet corn for yield, number of ears, ear length, tipfill, ear shape, and row configuration. The objectives of this research were to determine the effect and potential contribution of dent corn germplasm on stalk and root quality traits in sweet corn, to examine the variation for stalk and root quality traits in some sweet corn germplasm, and to evaluate the utility of some traits used in improving root and stalk quality in dent corn for sweet corn improvement.

\section{Materials and Methods}

To evaluate the potential contributions of dent corn germplasm for improving stalk and root quality in sweet corn, we used a design II mating design (Comstock and Robinson, 1948), with 20 dent $\times$ sweet hybrids and a half diallel consisting of 10 sweet $\times$ sweet hybrids without parents or reciprocals (Griffing's experimental 


\begin{tabular}{|c|c|c|c|c|c|c|c|c|}
\hline & \multicolumn{2}{|c|}{$\begin{array}{c}\text { Stalk } \\
\text { lodging } \\
(\%)\end{array}$} & \multicolumn{2}{|c|}{$\begin{array}{l}\text { Root } \\
\text { lodging } \\
(\%)\end{array}$} & \multicolumn{2}{|c|}{$\begin{array}{c}\text { Root } \\
\text { pull } \\
\text { (load-kg/plant) }\end{array}$} & \multicolumn{2}{|c|}{$\begin{array}{c}\text { Crushing } \\
\text { strength } \\
\text { (load-kg/plant) }\end{array}$} \\
\hline & D2 & Dial & $\mathrm{D} 2$ & Dial & D2 & Dial & D2 & Dial \\
\hline 1988 & $4 . \overline{7}$ & 21.2 & 3.9 & 25.8 & 122 & 69.0 & 193 & 120 \\
\hline \multirow[t]{2}{*}{1989} & 4.2 & 16.2 & 18.4 & 25.8 & 155 & 71.0 & 127 & 46.1 \\
\hline & NS & NS & $*$ & NS & $*$ & NS & $*$ & $*$ \\
\hline \multirow[t]{2}{*}{ Mean } & 4.4 & 18.7 & 11.5 & 25.8 & 139.6 & 70.0 & 158.5 & 83.1 \\
\hline & \multicolumn{2}{|c|}{$*$} & \multicolumn{2}{|c|}{ NS } & \multicolumn{2}{|c|}{ NS } & \multicolumn{2}{|c|}{$*$} \\
\hline \multicolumn{9}{|l|}{1989 controls } \\
\hline $\mathrm{A} 632 \times \mathrm{B} 73$ & \multicolumn{2}{|c|}{0.0} & \multicolumn{2}{|c|}{3.6} & \multicolumn{2}{|c|}{185} & \multicolumn{2}{|c|}{212} \\
\hline A632 $\times$ Mol7 & \multicolumn{2}{|c|}{0.9} & \multicolumn{2}{|c|}{14.8} & \multicolumn{2}{|c|}{176} & \multicolumn{2}{|c|}{249} \\
\hline
\end{tabular}

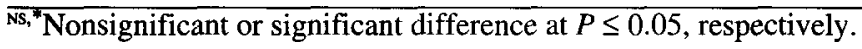

method 4, 1956). The following dent corn inbreds, converted to sugaryl (sul) endosperm by D.V. Glover of Purdue Univ., were used as males in the design II: A632, B73, B84, and Mo17. A632, B73, and B84 belong to the stiff-stalk heterotic group, and Mo17 is a Lancaster-type. The females-P39, P51, Ia191, CG4189, and CG2730 - have diverse backgrounds. Inbreds P39 and P51 are from 'Golden Bantam', Ia191 is a 'Narrow Grain Evergreen', and CG4189 and CG2730 have a 'Country Gentleman' background. The same five inbreds used as females in the design II were used in making the 10 hybrid half-diallel. In 1989, two control hybrids were included in the experiment. These hybrids, A632 × B73 and A632 $\times$ Mo17, were made with sugaryl endosperm conversions.

Seed of the design II and diallel hybrids was planted in the same trial in 1988 and 1989 at the West Madison Agricultural Research Station, Madison, Wis., in a Plano silt loam (fine-silty, mixed, mesic Typic Argiudolls). The design was a randomized complete block with three replications per year. Hybrids were considered fixed because the sweet corn inbreds were specifically chosen to represent different sweet corn backgrounds. Two-row plots, $5.3 \mathrm{~m}$ long with $0.76 \mathrm{~m}$ between rows, wereplanted with 40 seeds per row and thinned to an evenly spaced stand of 20 plants per row $(49,400$ plants/ha). Weeds were controlled with (in liter $\left.\cdot h^{-1}\right) 2.32-\{[4-$ chloro-6-(ethylamino)-1,3,5-triazin-2yl]amino $\}-2$ methylpropionitrile (cyanazine), 2.3 2-chloro- $N$ - (2,6-diethylphe-nyl)- $N$ (methoxymethyl)acetamide (alachlor), and cultivation in 1988; in 1989, 5.16-chloro- $N$ - ethyl $-N^{\prime}$-(1-methylethyl)-1,3,5-triazine-2,4diamine (atrazine) and 4.7 alachlor along with cultivation were used. Plots were irrigated twice in 1988 and once in 1989.

At $\approx 45$ days after silking, all traits were evaluated. Data were taken at 45 days after silking because the grain-filling period had finished and, differences among plots were maximized. The number of plants with stalk or root lodging, or both, was recorded. A plant was considered stalk-lodged if the stalk was broken below the upper ear. A plant was considered root-lodged if the stalk leaned more than 30" from vertical or if the stalk was curved (goosenecked) near the soil. Five nonconsecutive and competitive plants in one row of each two-row plot were pulled from the ground using a scale and special clamp attached to a tripod to determine the vertical root-pulling resistance.

Ten competitive plants in the second row of the two-row plot were cut at soil level. The first internode above the soil was removed and frozen with dry ice. These internodes were kept frozen at $-15 \mathrm{C}$ until soluble carbohydrates weight per stalk was determined. The second internode was removed and dried. This was used for measurement of stalk diameter, stalk section weight, rind thickness, and stalk crushing strength.
Stalk soluble carbohydrates were measured in the following manner: 1) internodes were thawed and pith bored with a $10-\mathrm{mm}$ diameter cork borer; 2) pith sections $30 \mathrm{~mm}$ long were weighed, placed in a small paper bag, dried at 49C, and reweighed to correct for moisture content in the stalk (Campbell and Hume, 1970); 3) juice from the remaining bore sample was placed on the prism of a hand refractometer ( $0 \%$ to $90 \%$ Brix) to determine percent Brix. Soluble carbohydrates in the pith, for a constant volume, were calculated as: $($ percent Brix $) \times($ fresh weight-dry weight $)=$ weight of stalk soluble carbohydrates.

A 51-mm stalk section was cut from the center of the dried internodes using a double-bladed circular saw. The diameter and weight of these sections were determined, and then the sections were placed on a hand-pumped press to measure the pressure (load-kg) required to crush the section. The pith from each dried internode was scraped from the rind and the thickness of the rind was measured using a pressure micrometer.

Analysis of data was based on plot mean using SAS statistical software (SAS Institute, 1985). Because of missing plots in 1988, the general linear model (GLM) procedure was used to partition the variance components. The hybrid sums of squares were partitioned into design II hybrids, diallel hybrids, and design II $\times$ diallel hybrids. The design II hybrids were further partitioned into males (GCA), females (GCA), and males $\times$ females [specific combining ability (SCA)]. The diallel hybrids were partitioned into GCA and SCA. The F tests of significance were performed using the appropriate error term, with years and replications random and hybrids fixed.

\section{Results and Discussion}

Interval to $50 \%$ silking ranged from 73.7 days for CG2730 $\times$ B84 to 65.7 days for P51 $\times$ Ia191. Because of this difference, the analysis of covariance procedure was performed on all traits, using days to $50 \%$ silking as the covariate to correct for the effect of maturity on the traits. This covariate was significant only for stalk diameter. Therefore, the mean squares, means, and phenotypic correlation coefficients for stalk diameter were calculated after adjusting for days to $50 \%$ silking.

Hybrid effects were significant $(\mathrm{P}<0.05)$ for all traits except percent root lodging, while year $\times$ hybrid effects were significant for all traits $(P<0.05)$. Years were significant $(P<0.05)$ for all traits except soluble carbohydrates and rind thickness. The significance of these effects establishes the diversity of the material used in this study and demonstrates the effect the environment can have on these traits in these hybrids. 


\begin{tabular}{|c|c|c|c|c|c|c|c|}
\hline \multicolumn{2}{|c|}{$\begin{array}{c}\text { Soluble } \\
\text { solids } \\
\text { (mg) }\end{array}$} & \multicolumn{2}{|c|}{$\begin{array}{c}\text { Rind } \\
\text { thickness } \\
(\mu \mathrm{m})\end{array}$} & \multicolumn{2}{|c|}{$\begin{array}{l}\text { Stalk } \\
\text { section } \\
\text { wt } \\
\text { (g/plant) }\end{array}$} & \multicolumn{2}{|c|}{$\begin{array}{l}\text { Stalk } \\
\text { diam } \\
(\mathrm{mm})\end{array}$} \\
\hline $\mathrm{D} 2$ & $\overline{\text { Dial }}$ & $\overline{\mathrm{D} 2}$ & Dial & $\overline{\mathrm{D} 2}$ & $\overline{\text { Dial }}$ & $\bar{D} 2$ & Dial \\
\hline$\overline{46.3}$ & 38.2 & 752 & 483 & 1.81 & 1.25 & 1.83 & $\overline{1.39}$ \\
\hline 47.6 & 42.8 & 834 & 497 & 2.19 & 1.39 & 2.26 & 1.74 \\
\hline NS & NS & NS & NS & $*$ & * & * & $*$ \\
\hline 47.0 & 40.5 & 795.1 & 490.3 & 2.01 & 1.32 & 2.04 & 1.57 \\
\hline \multicolumn{2}{|c|}{ * } & \multicolumn{2}{|c|}{ NS } & \multicolumn{2}{|c|}{ NS } & \multicolumn{2}{|c|}{ NS } \\
\hline \multicolumn{2}{|c|}{94.8} & \multicolumn{2}{|c|}{1248} & \multicolumn{2}{|c|}{3.4} & \multicolumn{2}{|c|}{2.69} \\
\hline \multicolumn{2}{|c|}{63.6} & \multicolumn{2}{|c|}{1296} & \multicolumn{2}{|c|}{3.2} & \multicolumn{2}{|c|}{2.79} \\
\hline
\end{tabular}

A goal of this study was to compare design II hybrids, which involved dent corn parents, with diallel hybrids, which involved only sweet corn parents. In this regard, design II vs. diallel effects were highly significant for percent stalk lodging, soluble carbohydrates, and crushing strength, while the year $\times$ design II vs. diallel effects were significant or highly significant for the rest of the traits. For percent stalk lodging, all of the variation among hybrids was explained by the design II vs. diallel. The hybrids in the design II had about one-fourth as much stalk lodging as the diallel (Table 1). The range for stalk lodging for the hybrid means in the design II was from $0.6 \%$ for CG2730 $\times$ B 84 to $12.9 \%$ for Ia $191 \times$ B 84 . Stalk lodging for hybrids in the diallel ranged from $14.7 \%$ for CG4189 × P39 to $28.9 \%$ for CG4189 × P51. The hybrid in the design II with the second highest degree of stalk lodging was CG4189 × A632, with $12.2 \%$, and this was significantly less than the hybrid with the least amount of stalk lodging in the diallel, CG4189 × P39 with $14.7 \%$.

Although hybrids in the design II averaged $11.5 \%$ root lodging, while those in the diallel had over twice that amount, the design II vs. diallel effect was not significant. This result can be explained by the year interaction. The mean root lodging for the design II was $3.9 \%$ in 1988 and $18.4 \%$ in 1989 , while the diallel averaged $25.8 \%$ root lodging for both years (Table 1). Root-pull resistance, like root lodging, was another trait in which the design II was affected by years but the diallel was not (Table 1). The design II root-pull average was $27 \%$ higher in 1989 than in 1988. The diallel was similar in both years; i.e., $\approx 70$ load-kg/plant. For individual hybrid means, the design II had a range (in load-kg/plant) of 91.2 for P51 $\times$ Mo17 to 185 for CG2730 $\times$ B73, and the diallel ranged from 51.2 for P51 $\times$ P39 to 87.2 for CG2730 × Ia191. The $\operatorname{LSD}(0.05)$ over all hybrids for root-pull resistance was 7.6 load-kg/plant.

For all traits except rind thickness, when the mean of the design II was not significantly different from the mean of the diallel, yearly means for the design II or diallel or both were significantly different (Table 1). Rind thickness had a high variation for replications within years for the design II and the diallel, thus making the difference in yearly means within either mating design nonsignificant. The range for the design II hybrids for rind thickness was from 635 to $1035 \mu \mathrm{m}$, while the diallel ranged from 377 to $654 \mu \mathrm{m}$. Seventeen of the 20 design II hybrids had a significantly thicker rind than the best diallel hybrid, CC2730 $\times$ Ia191, with $654 \mu \mathrm{m}$. For crushing strength, 18 of the 20 hybrids in the design II were significantly higher than the highest hybrid in the diallel. The range (in load-kg/plant) for the design II was from 93.9 to 242, compared with 52.3 to 109 for the diallel hybrids. Soluble carbohydrates for the design II ranged from $31.3 \mathrm{mg}$ for P51 × B84 to $66.8 \mathrm{mg}$ for
CG2730 × B73. In the diallel, the hybrid P39 $\times$ Ia191 had the lowest stalk soluble carbohydrates with $29.4 \mathrm{mg}$, and P39 $\times$ CG2730 had the highest with $57.7 \mathrm{mg}$. The design II hybrids ranged from 1.41 to $2.77 \mathrm{~g}$ for stalk weight and from 1.68 to 2.55 $\mathrm{mm}$ in stalk diameter. The diallel hybrids ranged from 0.92 to 1.67 $\mathrm{g}$ for stalk weight and from 1.37 to $1.89 \mathrm{~mm}$ for stalk diameter.

The interactions of the environment with other sources of variation mask some of the effect that the dent corn males had on these traits. Comparing the means of all hybrids, it is clear that those hybrids having a dent corn parent had better stalk and root quality traits than did the hybrids from the diallel. The range in trait values over hybrids helps exemplify this point. The favorable contribution of dent corn to sweet corn for stalk quality is not unexpected since dent corn has been selected intensively for improved stalks and roots, while sweet corn has not. However, until now, the magnitude of difference between the two germplasm groups has not been demonstrated under experimental conditions and without the confounding effects of different endosperm types.

The design II hybrid effects were significant for all traits except percent stalk lodging. Either the male effects or year $\times$ male effects were significant for all traits except percent stalk lodging, percent root lodging, and soluble carbohydrates. When the year $\times$ male effects were significant, the male effects were not significant. Thus the lack of significance for males for root pull, stalk section weight, crushing strength, and stalk diameter may be explained by the interaction of males with years. Effects due to females, year $x$ females, or both were significant or highly significant for all traits except percent stalk lodging. Male $\times$ female effects were highly significant for root lodging and rind thickness. Among the design II hybrids averaged over male inbreds, CG2730 had the highest root pull resistance, crushing strength, rind thickness, stalk diameter and stalk section weight (Table 2). Inbred P51 contributed the least to stalk and root quality in the design II. It had the lowest root pull resistance, crushing strength, rind thickness, stalk section weight, and stalk diameter (Table 2).

The effects due to the diallel hybrids were highly significant for stalk section weight, rind thickness, and stalk diameter. General combining ability effects for the diallel were significant for root pull, stalk section weight, rind thickness, and stalk diameter, while SCA effects were not significant for any trait. Year interactions with the diallel hybrids, GCA, and SCA also existed, again showing the importance of the environment on the expression of these traits in these hybrids.

The diallel had eight significant correlations, while the design II had 15 (Tables 3 and 4). Because the means of the design II and diallel were so different, the phenotypic correlations were calcu- 
Table 2. Means for the hybrids in the design II and diallel experiments grouped by common corn inbred parent.

\begin{tabular}{|c|c|c|c|c|c|c|c|c|}
\hline Hybrid & $\begin{array}{c}\text { Stalk } \\
\text { lodging }\end{array}$ & $\begin{array}{c}\text { Root } \\
\text { lodging }\end{array}$ & $\begin{array}{l}\text { Root } \\
\text { pull } \\
\text { (load }\end{array}$ & $\begin{array}{l}\text { Crushing } \\
\text { strength } \\
\text { plant) }\end{array}$ & $\begin{array}{c}\text { Soluble } \\
\text { solids } \\
\text { (mg) }\end{array}$ & $\begin{array}{c}\text { Rind } \\
\text { thickness } \\
(\mu \mathrm{m})\end{array}$ & $\begin{array}{c}\text { Stalk } \\
\text { section } \\
\text { wt } \\
\text { (g/plant) }\end{array}$ & $\begin{array}{l}\text { Stalk } \\
\text { diam } \\
(\mathrm{mm})\end{array}$ \\
\hline \multicolumn{9}{|c|}{ Design II } \\
\hline A632 & 6.4 & 14.8 & 138 & 147 & 47.1 & 733 & 1.95 & 1.99 \\
\hline B73 & 2.8 & 11.3 & 149 & 182 & 50.0 & 844 & 2.19 & 2.16 \\
\hline Mol7 & 2.6 & 11.2 & 125 & 143 & 43.4 & 772 & 1.84 & 1.94 \\
\hline B84 & 5.7 & 8.8 & 143 & 166 & 46.8 & 825 & 2.03 & 2.10 \\
\hline $\operatorname{LSD}(0.05)$ & NS & NS & NS & NS & NS & 32.0 & NS & NS \\
\hline P39 & 2.2 & 4.9 & 136 & 142 & 45.2 & 773 & 1.79 & 1.79 \\
\hline P51 & 5.5 & 7.7 & 119 & 115 & 36.7 & 665 & 1.54 & 1.79 \\
\hline Ial91 & 6.2 & 30.8 & 125 & 164 & 47.6 & 859 & 2.29 & 2.32 \\
\hline CG4189 & 6.3 & 9.7 & 138 & 146 & 44.4 & 738 & 1.86 & 1.95 \\
\hline CG2730 & 2.0 & 5.2 & 176 & 220 & 59.6 & 929 & 2.54 & 2.37 \\
\hline $\operatorname{LSD}(0.05)$ & NS & NS & 33.8 & 36.9 & NS & 116.3 & 0.10 & 0.19 \\
\hline \multicolumn{9}{|c|}{ Diallel } \\
\hline P39 & 17.3 & 22.1 & 63.2 & 74.0 & 41.8 & 466 & 1.23 & 1.51 \\
\hline P51 & 21.9 & 24.5 & 67.5 & 70.2 & 34.8 & 448 & 1.14 & 1.49 \\
\hline Ial91 & 16.6 & 37.4 & 68.7 & 95.1 & 38.6 & 553 & 1.51 & 1.69 \\
\hline CG4189 & 19.8 & 20.2 & 70.0 & 82.2 & 41.8 & 461 & 1.30 & 1.50 \\
\hline CG2730 & 17.8 & 24.8 & 80.5 & 94.1 & 45.3 & 524 & 1.43 & 1.65 \\
\hline $\operatorname{LSD}(0.05)$ & NS & NS & NS & NS & NS & 35.8 & 0.10 & 0.08 \\
\hline
\end{tabular}

Table 3. Phenotypic correlation coefficients for the five line diallel experiment grown in 1988 and 1989.

\begin{tabular}{|c|c|c|c|c|c|c|c|}
\hline & $\begin{array}{c}\text { Percent } \\
\text { root } \\
\text { lodging }\end{array}$ & $\begin{array}{l}\text { Root } \\
\text { pull }\end{array}$ & $\begin{array}{c}\text { Soluble } \\
\text { solids }\end{array}$ & $\begin{array}{c}\text { Stalk } \\
\text { section } \\
\text { wt }\end{array}$ & $\begin{array}{c}\text { Rind } \\
\text { thickness }\end{array}$ & $\begin{array}{l}\text { Crushing } \\
\text { strength }\end{array}$ & $\begin{array}{l}\text { Stalk } \\
\text { diam }\end{array}$ \\
\hline$\overline{\% \text { Stalk lodging }}$ & -0.11 & -0.17 & -0.39 & $-0.63^{*}$ & -0.54 & $-0.64^{*}$ & -0.53 \\
\hline$\%$ Root lodging & & -0.04 & 0.11 & 0.58 & 0.58 & 0.38 & 0.54 \\
\hline Root pull & & & 0.38 & 0.45 & 0.51 & 0.55 & 0.42 \\
\hline Soluble solids & & & & 0.44 & 0.15 & 0.34 & 0.08 \\
\hline Stalk section weight & & & & & $0.87^{* *}$ & $0.95^{* *}$ & $0.84^{* *}$ \\
\hline Rind thickness & & & & & & $0.83^{* *}$ & $0.94^{* *}$ \\
\hline Crushing strength & & & & & & & $0.87^{* *}$ \\
\hline
\end{tabular}

${ }^{*, * *}$ Significant difference from 0 at $P \leq 0.05$ and 0.01 , respectively.

Table 4. Phenotypic correlation coefficients for the design II experiment grown in 1988 and 1989.

\begin{tabular}{lccccccc}
\hline \multicolumn{1}{c}{ Percent } & Stalk & & & & & & \\
& $\begin{array}{c}\text { root } \\
\text { lodging }\end{array}$ & $\begin{array}{c}\text { Root } \\
\text { pull }\end{array}$ & $\begin{array}{c}\text { Soluble } \\
\text { solids }\end{array}$ & $\begin{array}{c}\text { section } \\
\text { wt }\end{array}$ & $\begin{array}{c}\text { Rind } \\
\text { thickness }\end{array}$ & $\begin{array}{c}\text { Crushing } \\
\text { strength }\end{array}$ & $\begin{array}{c}\text { Stalk } \\
\text { diam }\end{array}$ \\
\hline \% Stalk lodging & 0.21 & -0.30 & -0.27 & -0.20 & -0.40 & -0.29 & -0.08 \\
\% Root lodging & & -0.40 & -0.18 & 0.20 & 0.11 & -0.03 & 0.40 \\
Root pull & & & $0.82^{* *}$ & $0.70^{* *}$ & $0.63^{* *}$ & $0.76^{* *}$ & $0.53^{*}$ \\
Soluble solids & & & & $0.81^{* *}$ & $0.77^{* *}$ & $0.75^{* *}$ & $0.68^{* *}$ \\
Stalk section weight & & & & & $0.91^{* *}$ & $0.93^{* *}$ & $0.93^{* *}$ \\
Rind thickness & & & & & & $0.90^{* *}$ & $0.82^{* *}$ \\
Crushing Strength & & & & & & & \\
\end{tabular}

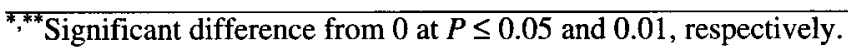

lated for both mating designs.

In the diallel, stalk section weight, rind thickness, crushing strength, and stalk diameter all correlated highly significantly (Table 3). Percent stalk lodging was negatively correlated with stalk section weight and crushing strength (Table 3 ). These two traits were among the easiest to measure and thus could be useful to sweet corn breeders wishing to improve stalk quality. While not significant, stalk section weight also had the highest correlation with root lodging. The most difficult trait to evaluate was root pull, which had a very low correlation coefficient $[r=(-0.04)]$ with root lodging. Even if the correlation had been much stronger, the difficulty in measuring root pull would exclude it as a useful tool in sweet corn improvement. In the design II experiment, significant correlations were observed between all pair-wise combinations of the following traits: root pull, soluble carbohydrates, stalk section weight, rind thickness, crushing strength, and stalk diameter (Table 4).

In these crosses, dent corn germplasm significantly improved 
stalk and root quality and stalk and root quality component traits. Even though the environment affected the design II and diallel differently for the different traits, the material in the design II was always better. In a segregating population containing dent and sweet germplasm, enough variation for stalk and root quality likely would be present to make selection effective.

If dent corn were used to improve sweet corn root and stalk quality, vigilance in maintaining and improving traits that determine sweet corn quality would be required (Haber 1945). However, the utility of exotic corn in sweet corn improvement has been demonstrated by Haber in developing the important inbred Ia2132, which is apparently $25 \%$ dent corn (Tracy, 1993), and by Rhodes and the development of Ill677a, which is $\approx 25 \%$ Bolivian flour corn (Ferguson et al., 1978). Commercial sweet corn breeders also have successfully used nonsweet germplasm in sweet corn improvement programs, but due to trade secrets, this is difficult to document. In a previous study using similar germplasm, Tracy (1990) demonstrated that field corn had positive effects on some ear appearance and plant performance traits. However, he did not evaluate eating quality, and this is the trait that will require the greatest attention (Haber 1945).

\section{Literature Cited}

Bauman, L.F. 1981. Review of methods used by breeders to develop superior corn inbreds, p. 199-208. In: H.D. Loden and D. Wilkinson (eds.). Proc. 36th Annu. Corn and Sorghum Res. Conf., Amer. Seed Trade Assn., Washington, D.C.

Campbell, D.K. and D.J. Hume. 1970. Evaluation of a rapid technique for measuring soluble solids in corn stalks. Crop Sci. 10:625-626.

Chang, H.S. and P.J. Loesch, Jr. 1972. Genetic variation of four anatomical traits and their association with stalk quality traits in maize (Zea mays L.). Crop Sci. 12:271-274.

Cloninger, F.D., M.S. Zuber, O.H. Calvert, and P.J. Loesch, Jr. 1970. Methods of evaluating stalk quality in corn. Phytopathology 60:295-300. Colbert, T.R. and M.S. Zuber. 1978. Effects of sampling dates on estimates of stalk quality in maize. Can. J. Plant Sci. 58:319-323.

Comstock, R.E. and H.F. Robinson. 1948. The components of genetic variance in populations of biparental progenies and their use in estimating the average degree of dominance. Biometrics 4:254-266.

Ferguson, J.E., A.W. Rhodes, and D.B. Dickinson. 1978. The genetics of sugary enhancer $(s e)$ an independent modifier of sweet corn $(s u)$. J. Hered. 69:377-380

Griffing, B. 1956. Concept of general and specific combining ability in relation to diallel crossing systems. Austral. J. Biol. Sci. 9:463-493.

Haber, E.S. 1945. Dent, flint, flour, and waxy maize for the improvement of sweet corn inbreds. Proc. Ann. Soc. Hort. Sci. 46:293-294.

Kevern, T.C. and A.R. Hallauer. 1983. Relation of vertical root-pull resistance and flowering in maize. Crop Sci. 23:357-363.

Loesch, P.J., Jr. 1972. Diallel analysis of stalk quality traits in twelve inbred lines of maize. Crop Sci. 12:261-264.

Loesch, P.J., Jr., M.S. Zuber, and C.O. Grogan. 1963. Inheritance of crushing strength and rind thickness in several inbred lines of corn. Crop Sci. 3:173-174.

Mortimore, C.G. and G.M. Ward. 1964. Root and stalk rot of corn in southwestern Ontario. III. Sugar levels as a measure of plant vigor and resistance. Can. J. Plant Sci. 44:451-457.

Russell, W.A. 1986. Contribution of breeding to maize improvement in the United States, 1920's-1980's. Iowa State J. of Res. Aug. 61:(1)5-34.

SAS Institute. 1985. 1985 SAS users guide: Statistics. Version 6 ed. SAS Institute, Cary, N.C.

Tracy, W.F. 1990. Potential of field corn germplasm for the improvement of sweet corn. Crop Sci. 30:104-1045.

Tracy, W.F. 1993. Sweet corn, p. 777-807. In: G. Kalloo and B.O. Bergh (eds.). Genetic improvement of vegetable crops. Pergamon, Oxford, U.K.

Twumasi-Afriyie, S. and R.B. Hunter. 1982. Evaluation of quantitative methods for determining stalk quality in short-season corn genotypes. Can. J. Plant Sci. 62:55-60.

Zuber, M.S. and P.J. Loesch, Jr. 1962. A mechanical method of evaluating stalk lodging, p. 15-23. In: W. Heckendorn and J.I. Sutherland (eds.). Proc. 17th Annu. Corn and Sorghum Res. Conf., Amer. Seed Trade Assn., Washington, D.C.

Zuber M.S. and P.J. Loesch, Jr. 1966. Effects of years and locations on stalk strength in corn. Agron. J. 58: 173-175. 